\title{
Article/Artigo
}

\section{Health-related quality of life in patients with Chagas disease}

\author{
Qualidade de vida relacionada à saúde na doença de Chagas
}

\section{Bruna Guimarães Oliveiraa ${ }^{1,2}$, Mery Natali Silva Abreu ${ }^{2,3}$, Claudia Drummond Guimarães Abreu ${ }^{1,2}$, Manoel Otavio da Costa Rocha ${ }^{1,2}$ and Antonio Luiz Ribeiro ${ }^{1,2}$} \begin{abstract}
Introduction: Chagas disease $(\mathrm{ChD})$ is a chronic illness related to significant morbidity and mortality that can affect the quality of life ( $\mathrm{QoL})$ of infected patients. However, there are few studies regarding QoL in ChD. The objectives of this study are to construct a health-related $\mathrm{QoL}$ (HRQoL) profile of $\mathrm{ChD}$ patients and compare this with a non- $\mathrm{ChD}(\mathrm{NChD})$ group to identify factors associated with the worst $\mathrm{HRQ}$ oL scores in $\mathrm{ChD}$ patients. Methods: $\mathrm{HRQ}$ oL was investigated in 125 patients with $\mathrm{ChD}$ and $21 \mathrm{NChD}$ individuals using the Medical Outcomes Study 36-item Short-Form (SF-36) and the Minnesota Living with Heart Failure Questionnaire (MLWHFQ). Patients were submitted to a standard protocol that included clinical examination, ECG, Holter monitoring, Doppler echocardiogram and autonomic function tests. Results: HRQoL scores were significantly worse among the $\mathrm{ChD}$ group compared to the $\mathrm{NChD}$ group in the SF-36 domains of physical functioning and role-emotional and in the MLWHFQ scale. For the $\mathrm{ChD}$ group, univariate analysis showed that HRQoL score quartiles were associated with level of education, sex, marital status, use of medication, functional classification and cardiovascular and gastrointestinal symptoms. In the multivariate analysis, female sex, fewer years of education, single status, worst functional classification, presence of cardiovascular and gastrointestinal symptoms, associated illnesses, Doppler echocardiographic abnormalities and ventricular arrhythmia detected during Holter monitoring were predictors of lower HRQoL scores. Conclusions: $\mathrm{ChD}$ patients showed worse HRQoL scores compared to NChD. For the $\mathrm{ChD}$ group, sociodemographic and clinical variables were associated with worst scores.
\end{abstract}

Keywords: Quality of life. Chagas disease. SF-36. Minnesota Living with Heart Failure Questionnaire.

\section{RESUMO}

Introdução: A doença de Chagas (DCh) é associada à morbidade e mortalidade significativas e que pode afetar a qualidade de vida $(\mathrm{QV})$ dos pacientes infectados. Entretanto, encontramos poucos estudos sobre a QV na DCh. Os objetivos deste estudo são definir o perfil de qualidade de vida relacionada à saúde (QVRS) em pacientes com DCh, compará-lo com indivíduos sem a doença de Chagas (NDCh) e encontrar os fatores associados com os piores escores de QV para aqueles com DCh. Métodos: A QVRS foi investigada em 125 pacientes com DCh e 21 NDCh aplicando-se os questionários Medical Outcomes Study 36-item short-Form (SF36) e Minnesota Living With Heart Failure Questionanaire (MLWHFQ). Os pacientes foram submetidos a exame clínico, ECG, monitorização por Holter, Doppler ecocardiograma e testes de função autonômicas. Resultados: Os escores de QVRS nos domínios capacidade física e aspecto emocional do SF36 e na escala de MLWHFQ foram significativamente piores entre os pacientes com DCh. A análise univariada mostrou associação dos escores QVRS e nível de formação, gênero, situação conjugal, uso de medicamentos, classe funcional e sintomas cardiovasculares e gastrointestinais. Na análise multivariada, sexo feminino, poucos anos de estudos, situação conjugal de solteiro, pior classificação funcional, presença de sintomas cardiovasculares e gastrointestinais, doenças associadas, alteração ao Doppler ecocardiograma e arritmia ventricular ao Holter foram preditores de pior QVRS. Conclusões: Pacientes com DCh apresentaram piores escores de QVRS quando comparados com NDCh. Para o grupo com DCh, variáveis sociodemográficas e clínicas se associaram aos piores escores.

Palavras-chaves: Qualidade de vida. Doença de Chagas. SF-36. Minnesota Living with Heart Failure Questionnaire.

1. Hospital das Clínicas, Universidade Federal de Minas Gerais, Belo Horizonte, MG. 2. Faculdade de Medicina, Universidade Federal de Minas Gerais, Belo Horizonte, MG. 3. Escola de Enfermagem, Universidade Federal de Minas Gerais, Belo Horizonte, MG.

Address to: Dra. Bruna Guimarães Oliveira. HC/UFMG. Rua Ana de Carvalho da Silveira 269/802, 31140-440 Belo Horizonte, MG, Brasil.

Phone/Fax.: 5531 3423-8485

e-mail: brunago@hc.ufmg.br

Received in 04/07/2010

Accepted in 18/10/2010

\section{INTRODUCTION}

Evaluation of quality of life (QoL) has been increasingly used to monitor and manage care strategies, clinical investigations, allocation of resources and to monitor the integration of new technologies ${ }^{1-3}$. Focusing on clinical outcomes that have an impact on the patient's life is one of the principles of evidence-based medicine. Hence, QoL is not only a concern for patients, their families and doctors, but also for the health policy makers and the healthcare industry. Knowledge concerning the impact of diseases on the QoL of patients can improve planning and allocation of resources for research, training and health care ${ }^{4}$.

The definition and scope of the term quality of life requires a thorough discussion. In this article, healthrelated QoL (HRQoL) is taken to be a measure that quantifies the patient's perception of the functional effects of the illness and treatment on different aspects of life, considering the subjectivity of the physical, emotional and social dimensions ${ }^{5,6}$.

Generic and specific measurement instruments can be used to evaluate HRQoL. The generic instruments, such as health profiles and utility measurements, are applicable to a large variety of populations and pathologies, allowing for comparison of different groups. They are most appropriate to epidemiological studies and to planning and evaluation in the healthcare system. The utility measurements are most widely used for cost analysis. In contrast, specific instruments are directed at evaluating individual and specific aspects of HRQoL following illness, injury or medical intervention?

The generic Short-Form Health Survey (SF-36) was developed in the early $1990 \mathrm{~s}^{8}$ and has been translated into Portuguese and validated ${ }^{9}$. The SF-36 has proven to be very useful with general populations and specific subgroups for comparing the impact of diverse diseases and treatments. It is currently the most commonly used generic instrument in Brazilian and international studies. The MLWHFQ is a specific instrument for evaluating patients with heart failure developed by Rector et $\mathrm{al}^{10}$ and translated into Portuguese and validated ${ }^{11,12}$. 
Despite the recognized importance of using HRQoL instruments when evaluating the effects of diseases and their treatments, particularly chronic diseases ${ }^{4}$, very few studies exist in research databases involving HRQoL profiles of the $\mathrm{ChD}$ group.

Defined as the presence of infection from Trypanosoma cruzi, $\mathrm{ChD}$ is part of a group of diseases that affect vulnerable populations and is associated with underdevelopment and poverty. According to the report of the WHO Scientific Work Group, ChD still represented a health threat in Latin America in 2006. Considering the information from 21 countries where the disease is endemic, it is estimated that 7.7 million people are infected, presenting varying degrees of complications of medico-social significance ${ }^{13}$. ChD is one of the principal causes of death from infectious disease, with 10,000 deaths in $2008^{14}$.

In recent decades in Brazil, it is estimated that about 6,000 patients have died each year due to $\mathrm{ChD}$-related causes, despite the effectiveness of public policy measures. This means that it is still a significant public health problem, with about 3.5 million chronic patients remaining, of which about $20 \%$ to $30 \%$ present cardiac impairment ${ }^{15}$. It is a chronic disease that mainly affects individuals of productive age and can be incapacitating and debilitating. It is one of the main causes of early retirement and has had a large social, economic and cultural impact ${ }^{16}$. The great variation in the clinical development of $\mathrm{ChD}$, the lack of understanding of the mechanisms responsible for its progression and the wide spectrum of clinical, emotional and social manifestations ${ }^{17,18}$ add to the importance of investigating the impact of $\mathrm{ChD}$ on the $\mathrm{QoL}$ of the patients.

The objectives of this study were evaluate the HRQoL profile of $\mathrm{ChD}$ patients and compare it with a control group without Chagas disease $(\mathrm{NChD})$ to identify the factors associated with the worst scores and, consequently, poorer QoL.

\section{METHODS}

This transversal study was conducted between 2004 and 2006 at the Clinical Hospital of the Federal University of Minas Gerais and the Infectious and Orestes Diniz Parasitic Disease Training and Reference Center (CTR-DIP). The patients studied were participants in a longitudinal prospective study begun in 1998 entitled: Autonomic dysfunction in ChD: mechanisms and prognostic implications, which primarily involves patients without systemic illnesses who are or have been treated at the abovementioned health facility. During the follow-up evaluation, 165 patients, of which 139 were $\mathrm{ChD}$ and $26 \mathrm{NChD}$, were invited and agreed to participate. No additional exclusion criteria were used. The group was composed of those who provided free, informed consent. Nineteen patients were excluded because of incomplete exams. The group evaluated consisted of 146 patients, 125 with $\mathrm{ChD}$ and 21 healthy controls (NChD group). A definite serological status for $\mathrm{ChD}$ was defined by the presence of two or more different positive reactions to Tripanossoma cruzi (indirect immunofluorescence, ELISA, indirect haemagglutination or complement fixation) in patients at risk of infection.

Patients were subjected to an initial standardized consultation that was conducted by experienced cardiologists and trained personnel. The following information was gathered: I) demographic characteristics: sex, age, skin color, marital status and educational level; II) clinical features: systolic and diastolic arterial pressure, heart rate, weight, height and calculated body mass index, associated illnesses, use of continuous medication, the presence of cardiovascular and gastrointestinal $\mathrm{ChD}$-related symptoms; III) functional classification: using the Goldman scale, from Class I (no limitation to physical activities and absence of symptoms) to Class IV (incapacity in physical activities with symptoms even at rest ${ }^{19}$; IV) level of physical activity: subjects were classified into two groups according to the International Physical Activity Questionnaire (IPAQ) as insufficiently active (sedentary + irregularly active) and sufficiently active (regularly active + active, very active $)^{20,21}$;

Complementary tests included: ECG, 24-hour Holter monitoring, Doppler echocardiogram and autonomic function evaluation, including short tests (Valsalva maneuver and respiratory sinus arrhythmia) and 24-hour heart rate variability analysis. The methodology used for these tests has been previously described by our research group ${ }^{22,23}$. The examinations were conducted and analyzed by experienced cardiologists who were blind to the serological profile of the patients and used the following classification parameters: I) electrocardiogram: abnormal in accordance with the $\mathrm{ChD}$-specific Buenos Aires criterion ${ }^{24,25}$; II) ventricular arrhythmia detected during Holter monitoring: presence of nonsustained ventricular tachycardia or more than ten ventricular extrasystoles per hour ${ }^{25}$; III) abnormal Doppler echocardiogram considering the presence of one of the following abnormalities: left ventricular ejection fraction (LVEF) $<0.50$, right ventricle $(\mathrm{RV})>56 \mathrm{~mm}$, left atrium (LA) $>40 \mathrm{~mm}$, presence of apical aneurysm or alteration in contractility; IV) abnormal autonomic function tests, considering the presence of one of the following abnormalities: heart rate variability with a standard deviation for normal cardiac intervals $($ SDNN) $<75 \mathrm{~ms}$ on the $24 \mathrm{~h}$ recordings, Valsalva ratio $<1.5$ or respiratory sinus arrhythmia with a ratio of the greatest expiratory interval over the smallest inspiratory interval (mean of six respiratory cycles) $<1.1^{22,23}$.

To evaluate HRQoL, interviews were conducted by trained professionals using the SF-36 generic multidimensional questionnaire ${ }^{8}$ and the specific questionnaire MLWHFQ ${ }^{10}$

The SF-36 is divided into eight domains: physical functioning, role-physical, bodily pain, general health, vitality, social functioning, role-emotional and mental health, as well as into two summary components: physical component summary (physical functioning, role-physical, bodily pain, general health, vitality) and mental component summary (mental health, role-emotional, social functioning, vitality, and general health). The result is expressed as a score varying from 0 (the most impaired) to 100 (no impairment) 9 .

The MLWHFQ consists of 21 questions covering physical, socioeconomic and psychological dimensions of life relative to the limitations frequently associated with the profile of cardiac insufficiency. The final score is the sum of the responses and varies from 0 (no impairment) to 105 (total impairment). The higher the score, the worse the quality of life $\mathrm{f}^{12,26,27}$.

\section{Statistical analysis}

For the categorical variables, either the Chi square or Fisher exact tests were used to compare the demographic, clinical and complementary examination aspects of the $\mathrm{NChD}$ and $\mathrm{ChD}$ groups. For continuous variables, including the QoL scores, the MannWhitney test was used. In all analyses, a level of 5\% was considered to be significant. Nonparametric tests were chosen because of the asymmetric nature of the variables tested. 
To evaluate the factors associated with $\mathrm{QoL}$ in the $\mathrm{ChD}$ group, five different outcome variables were used: physical and mental component summary and domains which showed significant differences in QoL between the $\mathrm{ChD}$ and $\mathrm{NChD}$ groups, the physical functioning and role-emotional from the SF-36 scale, and the MLWHFQ. For all of the variables, except the SF-36 role-emotional scale, the Qol scores were coded with an ordinal variable with four categories, which used the quartiles as cutoff points. The roleemotional scale was not recoded because it always produces a variable with four categories: scores $0,33,67$, and 100 . The explanatory

TABLE 1 - Sociodemographic and clinical features and complementary test characteristics of non-Chagas disease $(\mathrm{NChD})$ and Chagas disease $(\mathrm{ChD})$ patients.

\begin{tabular}{|c|c|c|c|c|c|}
\hline \multirow[b]{2}{*}{ Variables } & \multicolumn{2}{|c|}{$\operatorname{NChD}(n=21)$} & \multicolumn{2}{|c|}{$\operatorname{ChD}(n=125)$} & \multirow[b]{2}{*}{$\mathrm{p}$-value } \\
\hline & $\mathrm{n}$ & $\%$ & $\mathrm{n}$ & $\%$ & \\
\hline
\end{tabular}

Sociodemographics

sex

\begin{tabular}{|c|c|c|c|c|c|}
\hline male & 13 & 62.0 & 72 & 58.0 & $0.711^{\mathrm{a}}$ \\
\hline \multicolumn{6}{|l|}{ skin color } \\
\hline white & 9 & 43.0 & 28 & 22.0 & \multirow[t]{3}{*}{$0.135^{\mathrm{a}}$} \\
\hline brown & 7 & 33.0 & 54 & 43.0 & \\
\hline black & 5 & 24.0 & 43 & 34.0 & \\
\hline \multicolumn{6}{|l|}{ marital status } \\
\hline with partner & 15 & 71.0 & 95 & 76.0 & $0.653^{\mathrm{a}}$ \\
\hline \multicolumn{6}{|l|}{ education level } \\
\hline up to 2 years & 11 & 52.0 & 89 & 71.0 & $0.019^{b}$ \\
\hline elementary school & 2 & 10.0 & 21 & 17.0 & \\
\hline secondary school or more & 8 & 38.0 & 15 & 12.0 & \\
\hline age (years) & \multicolumn{2}{|c|}{$46(28-71)$} & \multicolumn{2}{|r|}{$29(25-68)$} & $0.288^{c}$ \\
\hline
\end{tabular}

Clinical condition

functional classification

$\begin{array}{lrrrrr}\text { I } & 21 & 100.0 & 102 & 82.0 & 0.392^{\mathrm{b}} \\ \text { II or more } & 0 & 0.0 & 23 & 18.0 & \end{array}$

BMI

$\begin{array}{lrrrrr}\text { normal } & 3 & 25.0 & 29 & 44.0 & 0.022^{\mathrm{b}} \\ \text { overweight } & 4 & 33.0 & 31 & 47.0 & \\ \text { obese } & 5 & 42.0 & 6 & 9.0\end{array}$

IPAC

\begin{tabular}{lrrrrr} 
sedentary & 0 & 0.0 & 5 & 4.0 & $0.552^{\mathrm{b}}$ \\
irregularly active & 19 & 100.0 & 100 & 88.0 & \\
regularly active & 0 & 0.0 & 9 & 8.0 & \\
continued use of medicine & 0 & 0.0 & 55 & 44.0 & $<0.001^{\mathrm{a}}$ \\
associated illness & 5 & 24.0 & 47 & 38.0 & $0.222^{\mathrm{a}}$ \\
cardiovascular symptoms & 4 & 19.0 & 59 & 47.0 & $0.016^{\mathrm{a}}$ \\
gastrointestinal symptoms & 4 & 19.0 & 24 & 19.0 & $0.999^{\mathrm{b}}$ \\
heart rate (bpm) & & $68(56-80)$ & & $64(46-98)$ & $<0.001^{\mathrm{c}}$ \\
systolic arterial pressure (mmHg) & & $126(100-160)$ & & $126(100-180)$ & $0.001^{\mathrm{c}}$ \\
diastolic arterial pressure (mmHg) & & $80(70-90)$ & & $84(60-130)$ & $<0.001^{\mathrm{c}}$ \\
\hline mlementary tests & & & & & \\
bnormal ecg & 0 & 0.0 & 73 & 58.0 & $<0.001^{\mathrm{b}}$ \\
bnormal doppler echo & 3 & 16.0 & 61 & 56.0 & $0.001^{\mathrm{b}}$ \\
entricular arrhythmia (holter) & 2 & 10.0 & 48 & 43.0 & $0.005^{\mathrm{b}}$ \\
bnormal autonomic function & 5 & 24.0 & 63 & 55.0 & $0.009^{\mathrm{a}}$
\end{tabular}

Data are absolute numbers (percentage) or median values (minimum-maximum). NChD: non-Chagas disease, ChD: Chagas disease, BMI: body mass index, IPAC: International Physical Activity Questionnaire, ECG: electrocardiogram, Doppler Echo: Doppler echocardiogram. ${ }^{a}$ Chi square test, ${ }^{b}$ Fisher test, ${ }^{c}$ Mann-Whitney test. variables were the clinical, sociodemographic and complementary discrete distribution of data (sco. stereotype ordinal logistic regression model was also performed, but the results were similar to those of the proportional odds model,

The logistic regression procedure began with the selection of variables that had a $p$-value of $\leq 0.20$ in the univariate analysis and later was adjusted by eliminating individual variables. The criterion for the variables to remain in the final model was a $\mathrm{p}$ value $\leq 0.05$ (Wald test). The odds ratio (OR) and confidence interval $(\mathrm{CI})$ was estimated for each covariable. This model provides a single OR estimate for all of the categories compared, due to the proportional odds assumption, which was tested for all of the variables individually and for the final model. A deviance test was used to evaluate the model's goodness-of-fit ${ }^{29}$.

\section{Ethical considerations}

This study involved reciprocal agreement between the researcher and the research line coordinator and was assessed and approved by the COEP UFMG (Research Ethics Committee of the Federal University of Minas Gerais). All of the study participants signed the informed consent forms and received written examination results, as well as the recommendations and appropriate referrals, while being treated as usual in the specialized health unit.

The WHO's recommendations and the Helsinki Declaration of 1975 were taken into consideration, along with Resolution 196/96 of the Ministry of Health on Research involving Human Beings, to ensure that the rights and well-being of the subjects were respected.

\section{RESULTS}

Demographic, clinical, and complementary examination characteristics

The sociodemographic and clinical features and complementary test results of the $\mathrm{ChD}$ and NChD subjects are presented in Table $\mathbf{1}$. Significant differences were observed in the level of education, percentage of obese participants, frequency of use of medication, reports of cardiovascular symptoms, median cardiac frequency, systolic and diastolic arterial pressure, abnormal ECG, abnormal Doppler echocardiogram, ventricular arrhythmia detected during Holter monitoring and abnormality in the autonomic function tests. 


\section{Quality of life}

Table 2 shows that the QoL scores were significantly worse amongst the $\mathrm{ChD}$ group compared to the $\mathrm{NChD}$ group in the SF-36 domains of physical functioning and role-emotional. Poor QoL was also observed in the ChD group with the MLWHFQ scale. The SF-36 item evaluating the patient's perception of the development of their state of health over the past year did not show statistically significant differences between the groups, $9.6 \%$ of the $\mathrm{ChD}$ group considered that their state of health was worse or much worse compared to $0 \%$ of the NChD group. About $30 \%$ of the NChD considered that their health was better or much better, in contrast to $21.6 \%$ in the $\mathrm{ChD}$ group. In the two groups, the most common response was no change, as reported by $68.8 \%$ of the $\mathrm{ChD}$ and $61.9 \%$ of the $\mathrm{NChD}$ group.

Multivariate analyses using the ordinal logistic regression model are presented in Table 3. The models were well fitted, considering the Deviance test and the supposition of proportional odds; i.e., the single OR for all of the QoL categories compared were valid for all of the constructed models. The abnormal echo variable $(\mathrm{p}=0.063$ ) was kept in the model for the SF-36 physical summary score because of its clinical importance. The covariables associated with a poor QoL according to the final logistic regression model were: I) Medical Outcomes Study 36-item Short-Form (SF-36): a) physical component summary: poorer functional classification $(\mathrm{OR}=8.02,95 \% \mathrm{CI}=2.63-24.41)$, presence of cardiovascular symptoms $(\mathrm{OR}=4.12,95 \% \mathrm{CI}=1.78-9.55)$, and Doppler echocardiogram examination abnormalities $(\mathrm{OR}=2.05,95 \%$ $\mathrm{CI}=0.96-4.36)$; b) mental component summary: presence of cardiovascular symptoms $(\mathrm{OR}=2.69,95 \% \mathrm{CI}=1.26-5.78)$, female $\operatorname{sex}(\mathrm{OR}=2.49,95 \% \mathrm{CI}=4.31-20.66)$ poorer physical functioning $(\mathrm{OR}=2.49,95 \% \mathrm{CI}=1.12-5.52) ; \mathrm{c})$ physical functioning: less than two years of education $\left(\mathrm{OR}=16.82,95 \% \mathrm{CI}=4.10_{-}\right.$
TABLE 2 - Quality of life scores of non-Chagas disease (NChD) and Chagas disease $(\mathrm{ChD})$ groups.

\begin{tabular}{lccc}
\hline Quality of life variables & NChD $(\mathbf{n}=\mathbf{2 1})$ & $\mathbf{C h D}(\mathbf{n}=\mathbf{1 2 5})$ & $\mathbf{p}^{\text {-value }} \mathbf{~}$ \\
\hline SF-36 & & & \\
physical summary & $52(48-55)$ & $48(38-54)$ & 0.078 \\
mental summary & $55(51-57)$ & $53(43-58)$ & 0.446 \\
physical functioning & $95(85-100)$ & $85(65-95)$ & 0.011 \\
role-physical & $100(63-100)$ & $100(50-100)$ & 0.249 \\
bodily pain & $72(57-100)$ & $62(42-96)$ & 0.154 \\
general health & $72(62-85)$ & $67(50-82)$ & 0.108 \\
vitality & $80(60-83)$ & $75(55-85)$ & 0.490 \\
social functioning & $100(75-100)$ & $88(63-100)$ & 0.596 \\
role-emotional & $100(100-100)$ & $100(33-100)$ & 0.020 \\
mental health & $80(66-88)$ & $76(60-88)$ & 0.454 \\
MLWHFQ scale & $0(0-10)$ & $5(0-14)$ & 0.028 \\
\hline
\end{tabular}

NChD: non-Chagas disease, ChD: Chagas disease, SF-36: Medical Outcomes Study 36-item Short-Form, MLWHFQ: Minnesota Living with Heart Failure Questionnaire. Data are median (Q1-Q3). ${ }^{\mathrm{a}}$ Mann-Whitney test.

68.97), female sex $(\mathrm{OR}=3.36,95 \% \mathrm{CI}=1.51-8.72)$, presence of cardiovascular symptoms $(\mathrm{OR}=4.6,95 \% \mathrm{CI}=1.93-11.30)$, presence of gastrointestinal symptoms $(\mathrm{OR}=3.7,95 \% \mathrm{CI}=1.19-6.37)$, associated illness $(\mathrm{OR}=2.75,95 \% \mathrm{CI}=1.19-6.37)$, and ventricular arrhythmia detected during Holter monitoring ( $\mathrm{OR}=2.47$, 95\% $\mathrm{CI}=1.12-5.45)$; d) role-emotional: presence of cardiovascularsymptoms $(\mathrm{OR}=8.6,95 \% \mathrm{CI}=3.60-20.59)$ and female sex $(\mathrm{OR}=7.04,95 \%$ $\mathrm{CI}=3.4-16.32)$. II) Minnesota Living with Heart Failure Questionnaire (MLWHFQ): marital status (single) (OR $=2.30,95 \%$ $\mathrm{CI}=1.02-5.15)$, feweryears of education $(\mathrm{OR}=4.39,-95 \% \mathrm{CI}=1.37-14.13)$, poorer functional classification $(\mathrm{OR}=3.30,95 \% \mathrm{CI}=1.54-7.05)$, presence of cardiovascular symptoms $(\mathrm{OR}=9.11,95 \% \mathrm{CI}=3.93-21.12)$.

TABLE 3 - Model of multivariate analyses: associated factors with quality of life domain: physical and mental summaries, physical functioning and role-emotional of the SF-36 and Minnesota Living with Heart Failure Questionnaire (MLWHFQ) scales.

\begin{tabular}{|c|c|c|c|c|c|}
\hline Variables & $\begin{array}{c}\text { Physical } \\
\text { summary SF-36 }\end{array}$ & $\begin{array}{c}\text { Mental summary } \\
\text { SF-36 }\end{array}$ & $\begin{array}{c}\text { SF-36 } \\
\text { physical function }\end{array}$ & $\begin{array}{l}\text { SF-36 Role- } \\
\text { emotional }\end{array}$ & MLWHFQ \\
\hline Female & -- & $9.43[4.31-0.66]$ & $3.63[1.51-8.72]$ & $7.04[3.4-16.32]$ & - \\
\hline Marital status (single) & - & - & - & - & $2.30[1.02-.15]$ \\
\hline Education & -- & -- & $16.82[4.10-68.97]$ & -- & $4.39[1.37-14.13]$ \\
\hline \multicolumn{6}{|l|}{$<2$ years } \\
\hline Poorest functional classification & $8.02[2.63-24.41]$ & $2.49[1.12-5.52]$ & -- & - & $3.30[1.54-7.05]$ \\
\hline CVS & $4.12[1.78-9.55]$ & $2.69[1.26-5.78]$ & $4.67[1.93-11.30]$ & $8.61[3.60-20.59]$ & $9.11[3.93-21.12]$ \\
\hline GIS & - & - & $3.76[1.17-12.11]$ & - & - \\
\hline Associated illnesses & & - & $2.75[1.19-6.37]$ & -- & - \\
\hline Abnormal Doppler Echo & $2.05[0.96-4.36]$ & -- & - & -- & -- \\
\hline Ventricular arrhythmias (Holter) & - & - & $2.47[1.12-5.45]$ & - & -- \\
\hline Goodness-of-fit test & 0.74 & 0.73 & 0.99 & 0.10 & 0.93 \\
\hline Supposition proportional odds & 0.55 & 0.44 & 0.99 & 0.20 & 0.44 \\
\hline
\end{tabular}

Data are odds ratio with 95\% confidence interval. MLWHFQ: Minnesota Living with Heart Failure Questionnaire, SF-36: Medical Outcomes Study 36-item Short-Form, CVS: cardiovascular symptoms, GIS: gastrointestinal symptoms, Doppler Echo: Doppler echocardiogram, OR: odds ratio, CI: confidence interval. A p-value deviance score. 


\section{DISCUSSION}

Differences in the clinical, demographic and complementary examination characteristics of the Chagas disease and nonChagas disease groups and their association with quality of life

Considering the demographic and clinical differences found between the $\mathrm{ChD}$ and $\mathrm{NChD}$ groups and the results of complementary tests, a lower level of education, lower percentage of obesity and lower median functional class was verified in the $\mathrm{ChD}$ group. The same group showed greater rates of continuous use of medication, presence of cardiovascular symptoms, abnormalities in ECG and Doppler echocardiogram tests and autonomic function tests, greater ventricular arrhythmia detected during Holter monitoring, as well as greater median systolic and diastolic pressure. According to the relevant literature, the differences observed are related, either directly or indirectly, to the $\mathrm{ChD}$ profile and the potential development of cardiac disease. An exception was the smaller percentage of obesity in the group, since no specific data exists in the literature regarding this condition in $\mathrm{Ch}^{16,18,30-34}$.

The known vulnerability associated with underdevelopment and poverty, observed in the majority of the population affected by $\mathrm{ChD}^{35}$, was expressed in this study by the lower level of education verified in the $\mathrm{ChD}$ group. In the literature, this condition is highlighted as predictive of mortality from cardiovascular diseases ${ }^{26,36}$, and in this study, it was predictive of poorer HRQoL in the $\mathrm{ChD}$ group for the SF-36 physical functioning domain and the MLWHFQ scale.

Features identified in the $\mathrm{ChD}$ group, including a lower level of education, greater frequency of continuous medication use and greater presence of cardiovascular symptoms, were associated with poorer HRQoL scores. Such findings suggest that, in addition to the relevance of further study, a multidisciplinary health team is important in the development of a care model, as highlighted in the literature for patients suffering from chronic diseases ${ }^{4}$.

\section{Health-related quality of life of Chagas disease}

Reports in the literature indicate poorer HRQoL scores for individuals with chronic diseases, mainly in the case of diseases that are more symptomatic and cause greater incapacity ${ }^{3}$. Studies concerning QoL in ChD are scarce and most articles addressed this QoL issue in a generic sense, without using validated instruments. Some papers deal with specific conditions, such as those of pacemaker users, heart failure, or pre- and posttreatment evaluations, and do not describe the profile of $\mathrm{QoL}$ in $\mathrm{ChD}$ patients. Furthermore, some authors suggest that the putative relation between $\mathrm{ChD}$ and depression deserves to be elucidated ${ }^{37}$.

Four studies evaluated $\mathrm{ChD}$ patients using a validated QoL instrument (WHOQoL-bref), although with different methodologies. Hueb, using self-evaluations, reported that ChD subjects were significantly dissatisfied with their QoL, general health and daily activity performance in general ${ }^{38}$. Ozaki demonstrated that worse QoL scores correlated with a greater intensity of depression symptoms ${ }^{39}$. Dias verified the lowest score in the environment domain in $\mathrm{ChD}$. The worst perception of $\mathrm{QoL}$ in the physical domain was related to a greater number of associated diseases and cardiac and gastric forms of $\mathrm{ChD}$. The psychological and social relation domains were related to cardiac and gastric forms of $\mathrm{ChD}$, while the environment domain correlated with women ${ }^{40}$. Gontijo et $\mathrm{al}^{41}$ analyzed the QoL in $\mathrm{ChD}$ and verified that the cardiac form of the disease is associated with greater psychological suffering compared to the absence of cardiopathy and that faith helped to deal with the day-to-day difficulties.

In this study, the $\mathrm{ChD}$ group presented significantly worse scores for the SF-36 physical functioning and role-emotional domains and for the MLWHFQ. Studying pacemaker patients, Oliveira also reported that the SF-36 physical functioning scores were lower in the $\mathrm{ChD}$ group compared to a $\mathrm{NChD}$ group ${ }^{42}$. Hidden fear of the impossibility of stopping the disease and its possible malign development ${ }^{43}$ are perhaps expressed by the worse role-emotional score verified for the $\mathrm{ChD}$ group in this study.

Significant differences were observed in the HRQoL scores between the $\mathrm{ChD}$ and $\mathrm{NChD}$ groups only in the SF-36 domains of physical functionality and role-emotional and in the MLWHFQ. However, Table 2 shows that the medians of the scores in the $\mathrm{ChD}$ group were lower in all of the valid aspects, as also reported by $\mathrm{Hueb}^{38}$.

\section{Factors associated with the worst scores}

In the present study, it is noteworthy that being female appears to be a risk for over nine-fold poorer $\mathrm{QoL}$ for the mental components summary, seven-fold for the role-emotional domain and over threefold for the physical functioning domain, in agreement with data in the literature for other clinical conditions. It is interesting that the $\mathrm{ChD}$ literature indicates being male as a risk factor for more severe myocardial damage ${ }^{44}$. In addition, an abnormal ECG, which is recognized as a factor associated with an increased risk of events amongst $\mathrm{ChD}$ patients, did not correlate with poorer QoL. Such findings demonstrate the complementary nature of the HRQoL evaluation and that it adds valuable information to routine clinical methods by considering other aspects related to patient well-being.

It is also noteworthy that the presence of factors subject to intervention, such as associated illness and gastrointestinal and cardiovascular symptoms, negatively influenced the $\mathrm{QoL}$ of $\mathrm{ChD}$. The presence of cardiovascular symptoms, for example, impacted on five of the HRQoL aspects evaluated and the MLWHFQ score, indicating the great effect of this factor on the well-being of patients.

An abnormal Doppler echocardiogram, the presence of ventricular arrhythmia and poorer functional classification, indicated by Rassi et $\mathrm{a}^{32}$ as risk factors for sudden cardiac death due to cardiovascular causes, also appeared in this study as risk factors for poorer HRQoL in the $\mathrm{ChD}$ group. It is noteworthy that poorer functional classification increased the odds of poorer QoL eight-fold in the physical components summary and 17 -fold in the physical functioning domain.

\section{Limitations}

Some limitations of this study should be considered. The main limitation is the small available sample of $\mathrm{NChD}$ subjects. This study was conducted in patients followed in a longitudinal prospective study and it was not possible to recruit new patients, since all of them had been selected almost ten years before. It was not possible to retrieve some potentially significant information, because of the duration of residence in the rural area and of exposure to reinfection. The absence of SF-36 reference scores for the Brazilian population is also an important issue, since it prevents further comparison between $\mathrm{ChD}$ patients and other populations.

\section{Conclusions}

Chagas disease is related to the poorest QoL scores in the physical functioning and role-emotional domains of the SF-36 
generic questionnaire and the MLWHFQ specific questionnaire. The factors which stand out among those related to the worst scores in the $\mathrm{ChD}$ are being female, cardiovascular symptoms and poor functional classification. Although further studies are required in order to define SF-36 reference values for the Brazilian population, the data strongly suggest that the evaluation of HRQoL should be incorporated into clinical studies involving $\mathrm{ChD}$.

\section{CONFLICT OF INTEREST}

The authors declare that there is no conflict of interest.

\section{FINANCIAL SUPPORT}

\section{CNPq and FAPEMIG.}

\section{REFERENCES}

1. Badia X, Carne X. Evaluation of quality of life in clinical trials. Med Clin (Barc) 1998; 110:550-556.

2. Alonso J. The measurement of health related-quality of life in clinical research and practice. Gac Sanit 2000; 14:163-167.

3. Alonso J, Ferrer M, Gandek B, Ware Jr JE, Aaronson NK, Mosconi P, et al. Health related quality of life associated with chronic conditions in eight countries: results from the International Quality of Life Assessment (IQOLA) Project. Qual Life Res 2004; 13:283-298.

4. Sprangers MA, de Regt EB, Andries F, van Agt HM, Bijl RV, de Boer JB, et al Which chronic conditions are associated with better or poorer quality of life? J Clin Epidemiol 2000; 53:895-907.

5. Fitzpatrick R, Fletcher A, Gore S, Jones D, Spiegelhalter D, Cox D. Quality of life measures in health care. I: Applications and issues in assessment. Bmj 1992; 305:1074-1077.

6. Seidl EM, Zannon CM. Quality of life and health: conceptual and methodological issues. Cad Saude Publica 2004; 20:580-588.

7. Minayo MCS, Hartz ZMA, Buss PM. Qualidade de vida em saúde: um debate necessário. Cien Saude Colet 2000; 5:7-18

8. Ware Jr JE, Sherbourne CD. The MOS 36-item short-form health survey (SF-36) I. Conceptual framework and item selection. Med Care 1992; 30:473-483.

9. Ciconelli RM, Ferraz MB, Santos W, Meinao I, Quaresma MR. Tradução para a língua portuguesa e validação do questionário genérico de avaliação de qualidade de vida SF-36 (Brasil SF-36). Rev Bras Reumatol 1999; 39:143-150.

10. Rector TS, Kubo SH, Cohn JN. Patients self-assessment of their congestive heart failure, part 2: content, reliability and validation of a new measure, the Minnesota Living With Heart Failure Questionnaire. Heart Fail 1987; 3:198-219.

11. Carrara DE. Avaliação prospectiva da qualidade de vida em pacientes com miocardiopatia dilatada submetidos à ventriculectomia parcial esquerda. [Mestrado]. [São Paulo]: Universidade de São Paulo; 2001. 85p.

12. Carvalho VO, Guimarães GV, Carrara D, Bacal F, Bocchi A. Validação da versão em português do Minnesota Living With Heart Failure Questionnaire. Arq Bras Cardiol 2009; 93:39-44

13. World Health Organization. Programa Especial de Investigaciones y Ensenanzas sobre Enfermedades Tropicales. Report del grupo de trabajo cientifico sobre la enfermedad de Chagas [Internet]. Buenos Aires. Argentina: World Health Organization; 2007. [Cited 2009 June]. Available from: http://who.int/tdr/ publications/publications/pdf/swg_chagas.pdf/.

14. Organizacion Panamericana de la Salud. World Health Organization. Neglected Tropical Diseases. Intensified Disease Management Estimación cuantitativa de la enfermedad de Chagas en las Américas. Vigilancia Santaria Y Atención de las Enfermidades Transmisibles. [cited 2009 feb] Available from: http://who.int/ tdrold/publications/publications/pdf/swg_chagas.pdf/.

15. World Health Organization. New global effort to eliminate Chagas disease [Internet]. Genebra: World Health Organization; 2007. [cited 2010 June]. Available from http://www.who.int/mediacentre/factsheets/fs340/en/index.html/.
16. Ribeiro AL, Rocha MO. Indeterminate form of Chagas disease: considerations about diagnosis and prognosis. Rev Soc Bras Med Trop 1998; 31:301-314.

17. Hueb MFD, Loureiro SR. Revisão: aspectos cognitivos e psicossociais associados a doença de Chagas. Psicol Estud 2005; 10:137-142.

18. Rocha MO, Teixeira MM, Ribeiro AL. An update on the management of Chagas cardiomyopathy. Expert Rev Anti Infect Ther 2007; 5:727-743.

19. Goldman L, Hashimoto B, Cook EF, Loscalzo A. Comparative reproducibility and validity of systems for assessing cardiovascular functional class: advantages of a new specific activity scale. Circulation 1981; 64:1227-1334.

20. Matsudo S, Araujo T, Marsudo V, Andrade D, Andrade E, Oliveira LC, et al. Questionário internacional de atividade física (IPAC): estudo de validade e reprodutibilidade no Brasil. Rev Bras Ativ Fís Saude 2001; 6:5-18.

21. Hallal PC, Matsudo SM, Matsudo VKR, Araujo TL, Andrade DR, Bertoldi AD. Physical activity in adults from two Brazilian areas: similarities and differences. Cad Saude Publica 2005; 21:573-580.

22. Ribeiro AL, Moraes RS, Ribeiro JP, Ferlin EL, Torres RM, Oliveira E, et al Parasympathetic dysautonomia precedes left ventricular systolic dysfunction in Chagas disease. Am Heart J 2001; 141:260-265.

23. Oliveira E, Ribeiro AL, Assis Silva F, Torres RM, Rocha MO. The Valsalva maneuver in Chagas disease patients without cardiopathy. Int J Cardiol 2002; 82:49-54.

24. Lazzari JO, Pereira M, Antunes CM, Guimaraes A, Moncayo A, Chavez Dominguez R, et al. Diagnostic electrocardiography in epidemiological studies of Chagas' disease: multicenter evaluation of a standardized method. Rev Panam Salud Publica 1998; 4:317-330.

25. Goncalves JG, Prata A. A comparison of three electrocardiogram coding systems for chronic Chagas' disease. Rev Panam Salud Publica 2003; 14:201-208.

26. Liu K, Cedres LB, Stamler J, Dyer A, Stamler R, Nanas S, et al. Relationship of education to major risk factors and death from coronary heart disease, cardiovascular deseases and all causes. Findings of three Chicago epidemiologic studies. Circulation 1982; 66:1308-1314.

27. Scattolin FA, Diogo MJ, Colombo RC. Correlation between instruments for measuring health-related quality of life and functional independence in elderly with heart failure. Cad Saude Publica 2007; 23:2705-2715.

28. Abreu MNS, Siqueira AL, Cardoso CS, Caiaffa WT. Ordinal logistic regression models: application in quality of life studies. Cad Saude Publica 2008; 24: 5581-5591.

29. Abreu MNS, Siqueira AL, Caiaffa WT. Ordinal logistic regression in epidemiological studies. Rev Saude Publica 2009, 43:183-194.

30. Prata A. Clinical and epidemiological aspects of Chagas disease. Lancet Infect Dis 2001; 1:92-100.

31. Silva AS. Estudo caso controle de fatores associados à cardiopatia chagásica em pacientes com mais de 50 anos. [Mestrado]. [Belo Horizonte]: Faculdade de Medicina. Universidade Federal de Minas Gerais; 2006. 110p.

32. Rassi Jr A, Rassi A, Rassi SG. Predictors of mortality in chronic Chagas disease: a systematic review of observational studies. Circulation 2007; 115:1101-1108.

33. Ribeiro AL, Cavalvanti PS, Lombardi F, Nunes MC, Barros MV, Rocha MO Prognostic value of signal-averaged electrocardiogram in Chagas disease. J Cardiovasc Electrophysiol 2008; 19:502-509.

34. Ianni B. Diagnostico e prognostico da forma indeterminada da doença de Chagas: o que há de novo? Rev Soc Cardiol Estado São Paulo 2009; 19:6-15.

35. Fundação Oswaldo Cruz. Doença de Chagas [Internet]. Seção importância social. [cited 2008 June]. Available from: http://www.fiocruz.br?chagas/cgi/ cgilua.exe/sus/start.htm?sid=1 .

36. Lopes CC, Yamada A, Araujo F, Barreto AP, Mansur A. Socioeconomic factors in the prognosis of heart failure in a Brazilian cohort. Int J Cardiol 2005; 113: 181-187.

37. Mosovich SA, Mady C, Lopes N, Ianni B, Dias JC, Correia D, et al. Chagas disease as a mechanistic model for testing a novel hypothesis. Rev Soc Bras Med Trop 2008; 41:70-72.

38. Hueb MFD. Doença de Chagas: indicadores cognitivos, de transtorno orgânico cerebral, de uso de alcool e qualidade de vida. [Doutorado] [Ribeirão Preto]: Faculdade de Medicina de Ribeirão Preto. Universidade de São Paulo; 2006.156p. 
39. Ozaki Y. Qualidade de vida e sintomas depressivos em portadores da doença de Chagas em atendimento no ambulatório do grupo de estudos em doenças de Chagas. [Mestrado]. [Campinas]: Faculdade de Ciências Medicas. Universidade Estadual de Campinas; 2008. 112p.

40. Dias ELF. Qualidade de vida de adultos e idosos portadores da Doença de Chagas. [Mestrado]. [Campinas]: Faculdade de Ciências Medicas. Universidade Estadual de Campinas; 2009. 136p.

41. Gontijo ED, Guimarães TN, Magnani C, Paixão GM, Dupin S, Paixão LM. Qualidade de vida dos portadores de doença de Chagas. Rev Med Minas Gerais 2009; 19:281-285.

42. Oliveira BG. Medida da qualidade de vida em portadores de marcapasso: tradução e validação de instrumento especifico. [Mestrado]. [Belo Horizonte]: Escola de Enfermagem, Universidade Federal de Minas Gerais; 2003.116p.

43. Jorg M, Storino R, Sapino RV. Participacion encefalopatica en la enfermedad de Chagas cronica. Reflexiones derivadas de experiencia personal. Rev Soc Bras Med Trop 1994; 27:31-37.

44. Barretto AC, Arteaga E, Mady C, Ianni BM, Bellotti G, Pileggi F. Male sex. Prognostic factor in Chagas' disease. Arq Bras Cardiol 1993; 60:225-227. 